\title{
STRESS MAHASISWA DALAM MENGHADAPI PANDEMI COVID-19
}

\section{Queen Agave ( queenasiregar@gmail.com )}

\section{Latar Belakang}

Stres adalah bagian yang tidak bisa dihindarkan dalam kehidupan sehari-hari. Stres muncul dari berbagai sumber yang tidak terhitung disetiap situasi kehidupan manusia. Tekanan sehari-hari yang menumpuk juga bisa menimbulkan stress. Stres adalah bagian penting dalam kehidupan kita, sebagai akibat interaksi kita dengan lingkungan.

Setiap manusia pasti memiliki hambatan yang harus dilalui dalam hidupnya. Salah satu hambatan itu dapat terjadi pada masa pendidikan, lebih tepatnya pada saat di bangku kuliah. Bagi mahasiswa yang sedang menjalani pendidikan di perguruan tinggi, mereka dituntut untuk dapat menyelesaikan masa studinya dalam waktu yang telah ditentukan. Tuntutan yang dirasakan oleh mahasiswa didapat dari berbagai pihak, pihak akademik atau universitas, keinginan orangtua yang ingin melihat anaknya mendapatkan gelar sarjana, dan dorongan dari teman maupun keinginan dari diri sendiri.
Beberapa peristiwa selama hidup dapat menyebabkan stres, semua ini diacu sebagai peristiwa-peristiwa kehidupan yang sebagian besar tidak bisa dihindarkan dan kita harus mampu beradaptasi untuk menghadapinya. Peristiwa-peristiwa kehidupan tersebut harus dihadapi, misalnya sakit, kehilangan seseorang, masalah keuangan dan salah satunya adalah menghadapi perubahan belajar yang biasa tatap muka dikelas, beralih kepada online dalam masa pandemic covid 19 yang dapat menjadi stressor pada mahasiswa.

Kehidupan yang penuh stress pada saat ini, karena merebaknya pandemi yang disebabkan oleh virus Corona di Indonesia, banyak cara yang dilakukan oleh pemerintah untuk mencegah penyebarannya. Salah satunya adalah melalui surat edaran Kementrian Pendidikan dan Kebudayaan (Kemendikbud) Direktorat Pendidikan Tinggi No 1 tahun 2020 tentang pencegahan penyebaran Corona Virus Disease (Covid19) di perguruan tinggi. Melalui surat edaran teresebut pihak Kemendikbud memberikan instruksi kepada perguruan tinggi untuk 
menyelenggarakan pembelajaran jarak jauh dan menyarankan mahasiswa untuk belajar dari rumah masingmasing.

Banyak perguruan tinggi dengan sigap menanggapi instruksi tersebut, salah satunya Universitas Indonesia yang menerbitkan surat edaran tentang kewaspadaan dan pencegahan penyebaran infeksi Covid-19 di lingkungan UI. Di dalam surat tersebut dimuat 10 poin yang salah satunya berupa himbauan untuk mengubah pembelajaran tatap muka menjadi pembelajaran jarak jauh (Yandwiputra, 2020). Setidaknya terdapat 65 perguruan tinggi di Indonsesia yang menyelenggarakan pembelajaran dari rumah untuk mencegah penyebaran Covid-19 (CNNIndonesia, 2020).
Salah satu bentuk pembelajaran alternatif yang dapat dilaksanakan selama masa daruratCovid-19 adalah pembelajaran Jurnal Penelitian Bimbingan dan Konseling Vol 5 (2) 15 secara online. Menurut Moore, DicksonDeane, \& Galyen (2011) Pembelajaran online merupakan pembelajaran yang menggunakan jaringan internet dengan aksesibilitas, konektivitas, fleksibilitas, dan kemampuan untuk memunculkan berbaga jenis interaksi pembelajaran. Penelitian yang dikakukan oleh Zhang et al., (2004) menunjukkan bahwa penggunaan internet dan teknologi multimedia mampu merombak cara penyampaian pengetahuan dan dapat menjadi alternatif pembelajaran yang dilaksanakan dalam kelas tradisional. 


\section{Metode}

Metode ini menggunakan metode kualitatif analisis berlandaskan teori dari buku, jurnal, e-book ataupun sumber informasi lainnya yang memuat informasi dengan Psikosoial dan Budaya dalam Keperawatan. Dengan metode ini informasi pembahasan mengenai Psikosoial dan Budaya dalam keperawatan bagi seorang perawat dapat memahami dan mempelajari tentang Stress Mahasiswa dalam Menghadapi Pancemi Covid-19 


\section{Hasil}

Secara umum subyek penelitian ini memiliki tingkat stress sedang. Dari data kategorisasi memperlihatkan bahwa keaaan stressfull tetap ada. Subyek tetap mengalami keadaan yang tertekan akibat respon terhadap stressor yang mengancam (108 subyek berada pada tingkat stress 96,4\%).

Subyek tetap mengalami stress, mungkin disebabkan karena subyek penelitian benarbenar menyadari bahwa mereka harus menghadapi proses pembelajaran dari tatap muka beralih ke pembelajaran berbasis Online. Selain itu mereka menyadari perkuliahaan online ini membutuhkan kuota yang banyak dan sinyal atau jaringan yang bagus.
Menurut santrock (2003) ada berbagai faktor yang dapat mempengaruhi tingkat stress tersebut. faktor-faktor tersebut adalah strategi mempengaruhi tingkat stress tersebut adalah strategi coping yang digunakan, factor lingkungan, dan factor kognitif. Faktor-faktor inilah yang membuat tidak berada pada kategori strss yang tinggi.

Coping adalah suatu proses yang terjadi ketika individu berusaha untuk mengontrol adanya ketidakseimbangan antara tuntutan dengan sumberdaya yang dimiliki dalam situasi stress (Sarafino, 1990). Menyediakan kuota yang cukup dan melakukan kegiatan lain diluar kegiatan kuliah online adalah strategi coping yang mereka gunakan 


\section{Pembahasan}

\section{A. Stres}

Pengertian Stres Looker \& Geegson (2004) mendefinisikan stres sebagai sebuah keadaan yang dialami individu ketika terjadi sebuah ketidaksesuaian antara tuntutantututan yang dialami individu ketika terjadi sebuah ketidak sesuaian antara tuntutantuntutan yang diterima dan kemampuan untuk mengatasinya. Menurut CranwellWard (dalam Iswinarti \& Rahayu Siti, 1999) stres adalah fisiologis dan psikologis yang terjadi jika seseorang merasakan ketidakseimbangan antara tuntutan yang dihadapi dan kempuan untuk menghadapi tuntutan yang dihadapi. Sarafino dan smith (2012) megkonseptualisasikan stress kedalam tiga pendekatan yaitu, :

\section{a. Stres sebagai stimulus}

Pendekatan ini memiliki focus pada lingkungan, sumber stress hadir dalam bentuk keadaan yang mengancam dan membahayakan sehingga menimbulkan ketegangan. Sumber stress ini disebut stressor.

\section{b. Stres sebagai respon}

Fokus dari pendekatan ini adalah reaksi seseorang terhadap stressor. Reaksi ini muncul dalam dua bentuk yaitu psikologis dan fisiologis. Bentuk psikologis meliputi tingkah laku, pola pikir dan emosi. Bentuk fisiologis mencagkup gerakan tubuh yang meningkat detak jantung, mulut terasa kering. Respon psikologis dan fisiologis seseorang terhadap stressor dinamakan strain.

c. Stres sebagai proses Proses yang dimaksud meliputi stressor dan strain, ditambah dimensi yang penting yaitu hubungan antara individu dengan lingkungan. Termasuk dalam proses ini adalah interaksi dan penyesuaian diri yang berlangsung secara bekesinambungan dinamakan ransaksi anatra individu dan lingkungan, yang stau mempengaruhi dan dipengaruhi oleh yang lain

\section{B. Pembelajaran online (E-Learning)}

\section{Definisi e-learning}

Persepsi dasar e-learning Perkembangan sistem komputer melalui jaringan semakin meningkat. Intemet merupaka jaringan publik. Keberadaannya sangat diperlukan baik sebagai media informasi maupun komunikasiyang dilakukan secara bebas. Salah satu 
pemanfaatan internet adalah pada sistem pembelajaran jarak jauh melalui belajar secara elektronik atau yang lebih dikenal dengan istilah ELearning

\section{Pendakatan Pedagogik dalam Elearning Teknologi}

komunikasi secara umum dapat dikategorikan sebagai asynchronous dan synchronous. Asynchronous merupakan aktivitas yang menggunakan teknologi dalam bentuk blogs, wikis,and discussion boards. Dalam bentuk ini partisipan dapat mengembangkan ide atau saling bertukar ide atau informasi tanpa keterkaitan antara partisipan satu dengan partisipan lainnya pada waktu yang sama, sebagai contoh penggunaan e-mail termasuk asynchronous dimana pesan dapat dikirim atau diterima tanpa keduanya harus berpartisipan pada waktu yang bersamaan. Dalam hal ini seorang pengirim pesan atau informasi tertentu kapan saja yang ia perlukan. Pada sisi lainpenerima pesan tidak diharuskan mengakses pesan atau informasi tersebut pada waktu yang bersamaan.

\section{Pandemi Covid 19}

\author{
Pada 31 Desember 2019, WHO \\ China Country Office melaporkan kasus \\ pneumonia yang tidak diketahui etiologinya
}

di Kota Wuhan, Provinsi Hubei, China. Pada tanggal 7Januari 2020, China mengidentifikasi pneumonia yang tidak diketahui etiologinya tersebut sebagai jenis baru coronavirus (novel coronavirus). Pada awal tahun 2020 NCP mulai menjadi pendemi global dan menjadi masalah kesehatan di beberapa negara diluar RRC. Berdasarkan World Health Organization (WHO) kasus kluster pneumonia dengan etiologi yang tidak jelas di Kota Wuhan telah menjadi permasalahan kesehatan di seluruh dunia. Penyebaran epidemi ini terus berkembang hingga akhirnya diketahuibahwa penyebab kluster pneumonia ini adalah Novel

\section{Pembelajaran on-Line}

sebagai stressor Potret pendidikan di tengah pandemic dengan menggunakan sistem daring menimbulkan sejumlah masalah. Mulai dari fasilitas hingga teknisnya. Di berbagai tempat, kendala soal sinyal muncul, belum lagi harus mengisi kuota internet. Hal ini menimbulkan efek stress bagi pelajar, mahasiswa dan orangtua ( Republika.co.id). 
Dampak covid 19 dalam pembelajarran on-line yaitu;

1. Mayoritas pelajar dan mahasiswa menyatakan jenuh dan bosan dengan sistem belajar yang sekarang sedang dijalani

2. Pembelajaran online dirasa kurang efektif dan inovatif

3. Belajar disekolah dirasa lebih efektif dari pada belajar dari rumah.

4. Orangtua, pelajar dan mahasiswa tidak dipersiapkan sebelumnya dalam pembelajaran online

5. Masalah koneksi internet atau alat komunikasi canggih yang belum tentu dimiliki guru, dosen, pelajar dan mahasiswa

\section{E. Aspek-aspek Stres Pembelajaran Online (E-Learning) di masa Pandemic Covid 19}

Stress meupakan reaksi alami tubuh terhadap tekanan, tegangan dan perubahan dalam kehidupan, begitu juga dalam menghadapi pembelajaran online dimasa pandemic covid 19. Mahasiswa yang mengalami stress ( melakukan reaksi terhadap stress) termanifestasi dalam gejala emosional, kognitif,, perilaku dan fisiologis (Selye, dalam Hardjana,1994; Tan \& Chan, 2004): a. Gejala Emosional

Secara emosional, individu yang mengalami stress akan merasa takut dan khawatir, mudah marah, kehilangan rasa ketertarikan terhadap hal-hal disekitarnya, ketidakmampuan menikmati dirinya sendiri, membenci sekolah, tidak bergairah, gugup, merasa tidak aman dan was-was.

b. Gejala kognitif atau mental Manifestasi stress dapat berupa ketidakmampuan dalam berpikir, daya konsentrasi kurang, sering melamun, mjdah lupa, pikiran kacau, produktivitas atau prestasi belajar menurun, sering melakukan kesalahan dalam bekerja.

c. Gejala Fisiologis

Keluhan-keluhan fisik yang timbul seperti pusing atau sakit kepala, sakit perut, mual, muntah, susah bernapas, jantung berdebar, selera makan berubah (kehilangan napsu makan atau makan berlebihan), sering ke kamar mandi, susah tidur, mimi buruk, bangun terlalu awal, telapak tangan berkeringat, dan mudah lelah.

d. Gejala Perilaku

Stress termanifestasi dalam perilaku seperti suka menyerang, menarik diri 
dari pergaulan, dan berdiam diri, merusak dan menganggu, membolos sekolah, berbohong, menarik-narik rambut, menggigit kuku, mengigau, memaksa, menggertakan gigi, mencari-cari kesalahan orang lain, dan tidak percaya pada orang lain. 


\section{Penutup}

Saran Bagi Orangtua Beradasarkan hasil penelitian siswa yang menghadapi pembelajaran online mengalami tingkat stress yang sedangg. Oleh sebab itu, orangtua sebagai orang terdekat dengan subyek, mendampingi anak dalam pembelajaran online dengan membuat suasana rumah yang menyenangkan sesuai dengan kebiasaannya diusahakan untuk semakin ditingkatkan sehingga stress bisa berkurang. Orangtua dapat meningkatkan perhatian untuk merespon kebutuhan anak dalam pembelajaran online dalam hal motivasi, penyediaan kuota. 


\section{Daftar Pustaka}

1. Looker, T \& Gregson. O. 2004. Managing Stress: Mengatasi Stress secara Mandiri. Yogyakarta: Baca

2. Moore, J. L., Dickson-Deane, C., \& Galyen, K. (2011). E-Learning, online learning, anddistance learning environments: Are they the same? Internet and Higher Education. https://doi.org/10.1016/j.iheduc.2010 .10.001

3. Needlman.R. (2004). Adolesence Stress. http://www.drscpock.co./article/0.15 10.7961.00html (On-Line)

4. Iftakhar, S. (2016). GOOGLE CLASSROOM: WHAT WORKS AND HOW? Journal of Education and Social Sciences

5. Korucu, A. T., \& Alkan, A. (2011). Differences between m-learning (mobile learning) and elearning, basic terminology and usage of mlearning in education. Procedia - Social andBehavioral Sciences. https://doi.org/10.1016/j.sbspro.2011.04.029

6. Djuwari. 2008. Pergeseran Nilai-nilai Pedagogis. (On-Line). Diambil tanggal Agustus 2020 dari http://www.surya.co.id

7. Direktorat Pembinaan Sekolah Menengah Atas. 2006. Pedoman Penyusunan Bahan Ajar. Jakarta : Lukmana, Direktorat Pembinaan Sekolah Menengah Atas

8. Iswinarti dan Rahayu Siti. 1999. Tingkat Stress dan Prestasi Belajar Anak Usia Sekolah ang memperoleh Pengaayaan. Jurnal Psikodinamik, Volume 1, Nomer 3

9. Siahaan, Sudirman.2002."Studi penjajagan tentang Kemungkinan Pemanfaatan Internet Pembelajaran di SLTA di Wilayah Jakarta dan Sekitarnya" dalam Jurnal Pendiidkan dan Kebudayaan, Tahun ke-8, No.039, November 2002 Jakarta: Badan Penelitian dan Pengembangan Departemen Pendidikan Nasional

10. Onno W. Purbo. (2002). Teknologi Elearning Berbasis PHP dan MySQL. Diaksesdari http://id.wikipedia.org/wiki/Pembelaj aran_elektronik pada tanggal 23 Juni 2014. 